\title{
PENDEKATAN HUMANISTIK DALAM PENGEMBANGAN KURIKULUM PENDIDIKAN AGAMA ISLAM
}

\author{
Suprihatin \\ Sekolah Tinggi Agama Islam (STAI) Ahsanta Jambi Indonesia \\ Email: suprihatin.atin.priha@gmail.com
}

\begin{abstract}
Curriculum is a tool to achieve educational goals as well as guidance in the implementation of teaching in all types and levels of education. The development (developers) have discovered several approaches in curriculum development that is intended approach with how the strategy and the correct method by following these steps systematic development in order to obtain a better curriculum. One approach developed by the developer is a humanistic approach. Humanistic curriculum developed by education experts humanistic. The curriculum is based on the concept of the flow of private education (personalized education). This stream is more giving to the students the main venue. They proceed from the assumption that a child or student is first and foremost in education. He is a subject that became the center of education. They believe that students have potential, have the ability and strength to thrive. Humanistic education is expected to restore the role and function of man is to restore man to his nature as the best of creatures (khairu ummah). The purpose of emphasizing the humanistic curriculum in terms of personal development, integration and autonomy of the individual. This objective can be seen as a means of asserting themselves.
\end{abstract}

Keywords: education, Islamic education, curriculum, humanistic

\section{A. Pendahuluan}

Tujuan Pendidikan Nasional adalah mencerdaskan kehidupan bangsa dan mengembangkan manusia Indonesia seutuhnya, yaitu manusia yang beriman dan bertaqwa terhadap Tuhan Yang Maha Esa dan berbudi pekerti luhur, memiliki pengetahuan dan keterampilan, kesehatan jasmani dan rohani, kepribadian yang mantap dan mandiri serta rasa tanggung jawab kemasyarakatan dan kebangsaan. Untuk mencapai tujuan-tujuan yang diharapkan dalam pendidikan, jelas diperlukan adanya jalan atau sarana yang dapat mengantarkan pada tujuan tersebut. Adapun sarana atau jalan dalam istilah pendidikan sering disebut dengan kurikulum. 
Kurikulum merupakan salah satu komponen yang sangat menentukan dalam suatu sistem pendidikan, karena itu kurikulum merupakan alat untuk mencapai tujuan pendidikan dan sekaligus sebagai pedoman dalam pelaksanaan pengajaran pada semua jenis dan tingkat pendidikan. Setiap pendidik harus memahami perkembangan kurikulum, karena merupakan suatu formulasi pedagogis yang paling penting dalam konteks pendidikan, dalam kurikulum akan tergambar bagaimana usaha yang dilakukan membantu siswa dalam mengembangkan potensinya berupa fisik, intelektual, emosional, dan sosial keagamaan dan lain sebagainya.

Pengembangan kurikulum di Indonesia tidak dapat terlepas dari tujuan pendidikan nasional sebagaimana tertuang dalam Undang-undang Nomor 20 tentang Sistem Pendidikan Nasional tahun 2003 (UU Sisdiknas) pasal (3), yang menyebutkan bahwa "Pendidikan nasional berfungsi mengembangkan kemampuan dan membentuk watak serta peradaban bangsa yang bermanfaat dalam rangka mencerdaskan kehidupan bangsa, bertujuan untuk berkembangnya potensi peserta didik agar menjadi manusia yang beriman dan bertaqwa kepada Tuhan Yang Maha Esa, berakhlak mulia, sehat, berilmu, cakap, kreatif, mandiri, dan menjadi warga negara yang demokratis secara bertanggung jawab. ${ }^{1}$

Nasution dalam Rahmat Raharjo menyatakan bahwa kurikulum dalam pendidikan merupakan desain, blue print, atau a plan for learning dalam lingkup pendidikan yang bermuara pada komponen-komponen pembelajaran yang dilakukan melalui langkah-langkah penyusunan, pelaksanaan, dan penyempurnaan kurikulum atas dasar hasil penilaian yang dilakukan selama kegiatan pengembangan tersebut. ${ }^{2}$

Pendekatan dalam pengembangan kurikulum mempunyai arti yang sangat luas. Hal tersebut bisa berarti penyusunan kurikulum baru (curriculum contruction), bisa juga penyempurnaan terhadap kurikulum yang sedang berlaku (curriculum improvement). Di satu sisi pengembangan kurikulum berkaitan dengan penyusunan seluruh dimensi kurikulum mulai dari landasan, struktur dan penataan mata pelajaran, ruang lingkup (scope) dan urutan materi pembelajaran (sekuence), garis-garis program pembelajaran, sampai pengembangan pedoman pelaksanaan (macro curriculum). Di sisi lain

\footnotetext{
${ }^{1}$ Departemen Pendidikan Nasional, Undang-undang Nomor 20 Tahun 2003 tentang Sistem Pendidikan Nasional, (Jakarta: 2004)

${ }^{2}$ Rahmat Raharjo, Pengembangan dan Inovasi Kurikulum Membangun Generasi Cerdas dan Berkarakter untuk Kemajuan Bangsa, (Yogyakarta: Baituna Publishing, 2012), h. 16-17.
} 
pengembangan kurikulum berkaitan dengan penjabaran kurilukulum (GBPP) yang telah disusun oleh pusat ke dalam program dan persiapan pembelajaran yang lebih khusus (micro curriculum). Kegiatan yang terakhir ini biasanya dikerjakan oleh guru di sekolah, seperti penyusunan program tahunan, semester, bulanan, pokok bahasan atau modul. Kurikulum juga berarti kurikulum tertulis (written curriculum) atau dokumen kurikulum yang merupakan kurikulum potensial (potensial curriculum), dan bisa juga berarti kurikulum nyata, yaitu kurikulum yang benar-benar dilaksanakan dalam kegiatan pembelajaran (actual curriculum), atau sering juga disebut implementasi kurikulum (curriculum implementation). ${ }^{3}$

Dalam teori kurikulum setidak-tidaknya terdapat empat pendekatan yang dapat digunakan dalam pengembangan kurikulum, yaitu pendekatan subjek akademis, pendekatan humanistik, pendeketan teknologis, dan pendekatan rekontruksi sosial. Dengan memperhatikan karakteristik pendidikan agama Islam (PAI), maka pengembangan kurikulum pendidikan agama Islam (PAI) dapat menggunakan pendekatan eklektik, yakni dapat memilih yang terbaik dari keempat pendekatan tersebut sesuai karakteristiknya. ${ }^{4}$ Dari bebarapa pendekatan dari pengembangan kurikulum diatas, maka akan dijelaskan mengenai pendekatan humanistik.

\section{B. Pendekatan dalam Pengembangan Kurikulum}

Para pengembang (developers) telah menemukan beberapa pendekatan dalam pengembangan kurikulum yang dimaksudkan pendekatan cara kerja dengan menerapkan strategi dan metode yang tepat dengan mengikuti langkah-langkah pengembangan yang sistematis agar memperoleh kurikulum yang lebih baik. Pendekatan yang dikembangkan para pengembang adalah pendekatan subjek akademik, pendekatan humanistik, pendekatan teknologis, dan pendekatan rekontruksionalisme.

Nik Haryati mengemukakan beberapa pendekatan pengembangan kurikulum pendidikan agama Islam, di antaranya yaitu: pendekatan bidang studi (pendekatan subjek atau disipiln ilmu), pendekatan berorientasi pada tujuan, pendekatan dengan pola

\footnotetext{
${ }^{3}$ Binti Maunah, Pengembangan Kurikulum Berbasis Kompetensi, (Yogyakarta: Teras, 2009), h. 52.

${ }^{4}$ Muhaimin, Pengembangan Kurikulum Pendidikan Agama Islam di Sekolah, Madrasah dan Perguruan Tinggi, (Jakarta: PT Raja Grafindo Persada, 2007), h. 139.
} 
organisasi bahan, pendekatan rekontrusionalisme, pendekatan humanistik, pendekatan akutanbilitas. ${ }^{5}$

Dengan memperhatikan karakteristik pendidikan agama Islam, maka pengembangan kurikulum pendidikan agama Islam dapat menggunakan pendekatan eklektik, yakni dapat memilih yang terbaik dari keempat pendekatan (subjek akademis/humanistik/teknologis/rekontruksi sosial) tersebut sesuai dengan karakteristiknya.

\section{Pendekatan Pengembangan Kurikulum Pendidikan Agama Islam}

Pendekatan dalam pengembangan kurikulum merefleksikan pandangan seseorang terhadap sekolah dan masyarakat. Para pendidik umumnya tidak berpegang pada salah satu pendekatan secara murni tetapi menggunakan beberapa pendekatan yang sesuai. Pendekatan dalam pengembangan kurikulum baru (curriculum construction), bisa juga penyempurnaan terhadap kurikulum yang sedang berlaku (curriculum improvement). ${ }^{6}$

Pendekatan pengembangan kurikulum adalah cara kerja dengan menerapkan strategi dan metode yang tepat dengan mengikuti langkah-langkah pengembangan yang sistematis untuk menghasilkan kurikulum yang sistematis agar memperoleh kurikulum yang lebih baik. ${ }^{7}$ Pendekatan dapat diartikan sebagai titik tolak atau sudut pandang seseorang terhadap suatu proses tertentu. Istilah pendekatan merujuk kepada pandangan tentang terjadinya suatu proses yang sifatnya masih sangat umum. Dengan demikian, pendekatan pengembangan kurikulum menunjuk pada titik tolak atau sudut pandang secara umum tentang proses pengembangan kurikulum. ${ }^{8}$

Pengembangan kurikulum seyogyanya dilaksanakan secara sistemik berdasarkan prinsip terpadu yaitu memberikan petunjuk bahwa keseluruhan komponen harus tepat sekali dan menyambung secara integratif, tidak terlepas-lepas, tetapi menyeluruh.

${ }^{5}$ Nik Haryati, Pengembangan Kurikulum Pendidikan Agama Islam, (Bandung: Alfabeta, 2011),

${ }^{6}$ E. Mulyasa, Kurikulum Berbasis Kompetensi, Konsep, Karakteristik dan Implementasi, (Bandung: PT Remaja Rosdakarya, 2004), h. 65-66.

${ }^{7}$ Abdullah Idi, Pengembangan Kurikulum, Teori dan Praktik, (Yogyakarta: Ar-Ruzz Media, 2010), h. 200.

${ }^{8}$ Wina Sanjaya, Kurikulum dan Pembelajaran: Teori dan Praktik Pengembangan Kurikulum Tingkat Satuan Pendidikan, (Jakarta: Kencana, 2010), h. 77. 
Penyusunan komponen-komponen lainnya sehingga kurikulum benar-benar terpadu secara bulat (integratif) dan utuh. ${ }^{9}$

Dalam dunia pendidikan kurikulum selalu mengalami perubahan sejalan dengan kemajuan zaman dan pekembangan ilmu pengetahuan dan teknologi. Proses perubahan secara mendasar dan sistematis terhadap kurikulum yang dikembangkan dalam pendidikan sebenarnya merupakan proses transformasi pandangan dan aspirasi tentang pendidikan kedalam program-program yang secara efektif akan mewujudkan visi dan misi pendidikan itu sendiri. ${ }^{10}$ Dengan demikian, pengembangan kurikulum dimaknai sebagai suatu proses total dimana komponen-komponen yang berbeda seperti perencanaan kurikulum, implementasi dan penilaian kurikulum memainkan peranan yang penting. ${ }^{11}$

Kurikulum merupakan salah satu komponen penting dalam sistem pendidikan nasional. Kedudukan kurikulum berfungsi sabagai perangkat rencana dan pengaturan mengenai isi dan bahan ajar serta cara yang digunakan sebagai pedoman penyelenggaraan kegiatan pembelajaran. Kegiatan pembelajaran itu sendiri merupakan muara dari keseluruhan proses penyelenggaraan kurikulum. Perkembangan kurikulum diperlukan untuk membantu guru dalam mengembangkan pengetahuan, sikap, nilai, dan keterampilan dari berbagai bahan kajian dan pelajaran yang diperoleh oleh siswa sesuai dengan jenjang dan satuan pendidikan.

Dalam merumuskan perubahan-perubahan kurikulum perlu dipertimbangkan kemampuan guru dalam menyelenggarakan kegiatan pembelajaran melalui proses yang cukup komprehensif dan sistematis. Di samping itu dalam proses penyusunan kurikulum yang akan dikembangkan tersebut perlu melibatkan berbagai ahli yang memiliki disiplin ilmu yang berbeda-beda. Pengalaman berbagai negara menunjukkan bahwa pendekatan sentralisasi atau pendekatan disentralisasi tetap dipakai dan dibutuhkan dalam pengembangan kurukulum dan hal itu tergantung kepada sistem ketatanegaraan negara yang bersangkutan. ${ }^{12}$

\footnotetext{
${ }^{9}$ Agus Zaenal Fitri, Manajemen Kurikulum Pendidikan Islam, (Bandung: Alfabeta, 2013), h. 120.

${ }^{10}$ Husni Rahim, Arab Baru Pendidikan Islam di Indonesia, (Jakarta: Logos Wacana Ilmu, 2004). h. xi.

${ }^{11}$ Nik Haryati, Pengembangan Kurikulum..., h. 75.

${ }^{12}$ Ibid., h. 76.
} 
Menurut Audrey dan Howard Nichools dalam Arifin ${ }^{13}$ mengemukakan bahwa pengembangan kurikulum (curriculum development) adalah "the planning of learning opportunities intended to bring about certain desired in pupils, and assessment of the extend to which theses changes have taken place." Artinya, pengembangan kurikulum adalah perencanaan kesempatan-kesempatan belajar yang dimaksudkan untuk membawa peserta didik ke arah perubahan-perubahan yang diinginkan serta menilai hingga sejauh mana perubahan-perubahan itu telah terjadi pada diri peserta didik. Adapun yang dimaksud kesempatan belajar (learning opportunity) adalah hubungan yang telah direncanakan dan terkontrol antara peserta didik, guru, bahan, dan peralatan, serta lingkungan belajar. Semua kesempatan belajar yang direncanakan oleh guru bagi para peserta didik sesungguhnya adalah "kurikulum itu sendiri."

Berdasarkan pengertian tersebut, pengembangan kurikulum sesungguhnya adalah sebuah siklus, suatu proses berulang yang tidak pernah berakhir. Proses kurikulum itu sendiri terdiri atas empat unsur, yaitu:

1. Tujuan

Tujuan yaitu mempelajari serta menggambarkan semua sumber pengetahuan dan pertimbangan tentang tujuan-tujuan pengajaran, baik yang berkenaan dengan mata pelajaran (subject course) maupun kurikulum secara menyeluruh.

2. Metode dan material

Metode dan material yaitu mengembangkan serta mencoba menggunakan metode dan meterial sekolah untuk mencapai tujuan-tujuan yang serasi menurut pertimbangan guru.

3. Penilaian (assessment)

Penilaian yaitu menilai keberhasilan pekerjaan yang telah dikembangkan dalam kaitan dengan tujuan yang telah ditetapkan sebelumnya atau mengembangkan tujuan-tujuan baru.

\section{Umpan Balik (feedback)}

Umpan balik yaitu umpan balik dari semua pengalaman yang telah diperoleh, yang pada gilirannya menjadi titik tolak bagi studi selanjutnya.

Dengan demikian, dari penjelasan yang ada, pengembangan kurikulum merupakan rencana yang dilakukan di setiap lembaga pendidikan, yang dimana perubahan-perubahan ini dilakukan untuk membawa peserta didik ke arah perubahan yang diinginkan serta menilai sejauh mana perubahan itu terjadi pada diri peserta didik.

${ }^{13}$ Zainal Arifin, Pengembangan Manajemen Mutu Kurikulum Pendidikan Islam, (Jogjakarta: Diva Press, 2006), h. 42-43 


\section{Prinsip-Prinsip Pengembangan Kurikulum}

Prinsip-prinsip pengembangan kurikulum dibagi menjadi dua yaitu: 1) prinsip umum, prinsip umum diantaranya yaitu relevansi, fleksibilitas, kontinuitas/ kesinambungan, dan praktis; 2) prinsip khusus, prinsip khusus di antaranya yaitu prinsip yang berkenaan dengan tujuan pendidikan, prinsip yang berkenaan denganpemilihan isi pendidikan, prinsip yang berkenaan pemilihan proses belajar mengajar, prinsip yang berkenaan pemilihan media dan alat pengajar, prinsip yang berkenaan pemilihan kegiatan penilaian. $^{14}$

Ada beberapa prinsip dasar dan pendekatan yang digunakan dalam pengembangan kurikulum dimadrasah yaitu:

1. Sistematika dan sistemik

Sistematika dan sistemik yaitu kurikulum yang dikembangkan secara menyeluruh sebagai suatu sistem yang saling berkaitan dengan sistem lainnyadalam rangka pencapaian pendidikan.

\section{Kemitraan}

Kemitraan yaitu proses pengembangan kurikulum yang melibatkan berbagai unsur dan keahlian yang saling berkaitan dan mengatur unsur dan keahlian tersebut agar dapat bekerja sama dan berkontribusi secara proaktif dalam pencapaian tujuan penyusunan kurikulum.

3. Pengembangan

Pengembangan yaitu penempatan kurikulum sabagai instrumen bagi perubahan mendasar dalam mewujudkan tujuan pembangunan nasional dan berorientasi pada produk yang manpu meningkatkan keunggulan.

4. Relevansi

Relevansi yaitu perubahan kurikulum yang disesuaikan dengan kebutuhan pembangunan dan potensi daerah serta kebutuhan siswa. ${ }^{15}$

Berangkat dari beberapa prinsip dan pendekatan di atas, dapat dijelaskan bahwa pengembangan kurikulum pendidikan yang memiliki kualitas tinggi akan terwujud apabila proses penentuan perubahan kurikulum yang dilakukan oleh orang-orang kompeten, prosedur yang jelas, serta orientasi pada pendidikan kecakapan hidup.

\footnotetext{
${ }^{14}$ Agus Zaenul Fitri, Manajemen Kurikulum..., h. 117-119.

${ }^{15}$ Departeman Agama RI, Pedoman Umun Pelajaran Umum Madrasah Aliyah, (Jakarta: Direktorat Jenderal Kelembagaan Agama Depag RI, 2003), h. 5.
} 
Kecakapan yang dimiliki untuk berani menghadapi problema hidup dan kehidupan dengan wajar tanpa rasa tertekan, kemudian secara proaktif dan kreatif mencari serta menemukan solusi sehingga akhirnya mampu mengatasinya.

\section{E. Pendekatan Humanistik}

\section{Pengertian Pendekatan Humanistik}

Kurikulum humanistik dikembangkan oleh para ahli pendidikan humanistik. Kurikulum ini berdasarkan konsep aliran pendidikan pribadi (personalized education), yaitu John Dewey (progressive Education) dan J.J. Roasseau (Romantic Education). Aliran ini lebih memberikan tempat utama kepada siswa. Mereka bertolak dari asumsi bahwa anak atau siswa adalah yang pertama dan utama dalam pendidikan. Ia adalah subjek yang menjadi pusat kegiatan pendidikan. Mereka percaya bahwa siswa mempunyai potensi, punya kemampuan, dan kekuatan untuk berkembang. Para pendidik humanis juga berpegang pada konsep Gestalt, bahwa individu atau anak merupakan satu kesatuan yang menyeluruh. Pendidikan diarahkan kepada membina manusia yang utuh bukan saja dari segi fisik dan intelektual tetapi juga segi sosial dan afektif (emosi, sikap, perasaan, nilai, dan lain-lain).

Kurikulum humanistik dikembangkan oleh para ahli pendidikan humanistis. Aliran ini lebih memberikan tempat utama kepada siswa. Guru diharapkan dapat membangun hubungan emosional yang baik dengan peserta didiknya. Oleh karena itu, peran guru yang diharapkan diantaranya adalah sebagai berikut:

a. Mendengar pandangan realitas peserta didik secara komprehensif

b. Menghormati individu peserta didik

c. Tampil alamiah, otentik, tidak dibuat-buat. ${ }^{16}$

Dalam pendekatan humanistik ini, peserta didik diajar untuk membedakan hasil berdasarkan maknanya. Pendekatan pengembangan kurikulum ini melihat kegiatan sebagai sebuah manfaat untuk peserta dimasa depan.Sesuai dengan konsep yang dianut, yaitu aliran pendidikan pribadi (personalized education) pendekatan ini lebih memberikan tempat utama pada siswa. ${ }^{17}$

\footnotetext{
${ }^{16}$ Ibid., h. 142.

${ }^{17}$ Agus Zaenal Fitri, Manajemen Kurikulum..., h. 124.
} 
Kurikulum ini menekankan integritas, yaitu kesatuan perilaku bukan saja yang bersifat intelektual tetapi juga emosional dan tindakan. Beberapa acuan dalam kurikulum ini diantaranya yaitu:

a. Integritas semua domain efeksi peserta didik, yaitu emosi sikap, nilai-nilai, dan domain kognisi, yaitu kemampuan dan pengetahuan

b. Kesadaran dan kepentingan

c. Respon terhadap ukuran tertentu, seperti kedalaman suatu keterampilan.

Pendekatan humanistik dalam pengembangan kurikulum bertolak dari ide "memanusiakan manusia." Penciptaan konteks yang akan memberi peluang manusia untuk menjadi lebih humam, untuk mempertinggi harkat manusia merupakan dasar filosofi, dasar teori, dasar evaluasi dan dasar pengembangan program pendidikan. ${ }^{18}$

Sebelum menguaraikan lebih jauh tentang pendekatan humanistis tersebut, maka persoalan yang perlu dijawab adalah apa yang dimaksud dengan "memanusiakan manusia" itu? Dilihat dari proses kejadiannya, manusia itu terdiri atas dua subtansi, yaitu:

a. Subtansi jasad/materi

Subtansi jasad/materi ialah yang bahan dasarnya adalah dari materi yang merupakan bagian dari alam semesta ciptaan Allah Swt. Dan dalam pertumbuhan dan perkembangannya tunduk pada dan mengikuti sunnatullah (aturan, ketentuan, hukum Allah yang berlaku di alam semesta).

b. Subtansi non jasadi/immateri

Subtansi non jasadi/immateri ialah penghembusan/peniupan ruh (ciptaanNya) ke dalam diri manusia, sehingga manusia merupakan benda organik yang mempunyai hakikat kemanusiaan serta mempunyai berbagai alat potensial dan fitrah.

Atau menurut al-Farabi, manusia itu terdiri atas dua unsur yaitu: unsur berasal dari alam al-Khalq dan unsur berasal dari alam al-amr (ruh dari perintah Tuhan). Dari kedua subtansi tersebut, maka yang paling esensial adalah subtansi immateri atau ruhnya. Jasad hanyalah alat ruh di alam nyata. Suatu ketika alat (jasad) itu terpisah dari ruh. Perpisahan itulah yang disebut dengan peristiwa maut. Yang mati adalah jasad, sedangkan ruh akan melanjutkan eksistennya di alam barzakh. Manusia yang terdiri atas

\footnotetext{
${ }^{18}$ Muhaimin, Pengembangan Kurikulum..., h. 142.
} 
dua subtansi itu, telah dilengkapi dengan alat-alat potensial dan potensi-potensi dasar atau disebut fitrah, yang harus diaktualkan, dan ditumbuhkembangkan dalam kehidupan nyata di dunia ini melalui proses pendidikan, untuk selanjutnya dipertanggungjawabkan di hadapanNya kelak di akhirat. ${ }^{19}$

Pendidikan humanistik merupakan model pendidikan yang berorientasi dan memandang manusia sebagai manusia (humanisasi), yakni makhluk ciptaan Tuhan dengan fitrahnya. Maka manusia sebagai makhluk hidup, harus mampu melangsungkan, mempertahankan, dan mengembangkan hidupnya. Maka posisi pendidikan dapat membangun proses-proses humanisasi, artinya menghargai hak-hak asasi manusia, seperti hak untuk berlaku dan diperlakukan dengan adil, hak untuk menyuarakan kebenaran, hak untuk berbuat kasih sayang dan lain sebagainya.

Pendidikan humanistik diharapkan dapat mengembalikan peran dan fungsi manusia yaitu mengembalikan manusia kepada fitrahnya sebagai sebaik-baik makhluk (khairu ummah). Maka, manusia "yang manusiawi" yang dihasilkan oleh pendidikan yang humanistik diharapkan dapat mengembangkan dan membentuk manusia berpikir, berasa dan berkemauan dan bertindak sesuai dengan nilai-nilai luhur kemanusiaan yang dapat mengganti sifat individualistik, egoistik, egosentrik dengan sifat kasih sayang kepada sesama manusia, sifat menghormati dan dihormati, sifat ingin memberi dan menerima, sifat saling menolong, sifat ingin mencari kesamaan, sifat menghargai hakhak asasi manusia, sifat menghargai hak-hak asasi manusia, sifat mengahargai perbedaan dan sebagainya.

Menurut para humanis, kurikulum berfungsi menyediakan pengalaman (pengetahuan) berharga untuk membantu memperlancar perkembangan pribadi peserta didik. Tujuan pendidikan adalah proses perkembangan pribadi yang dinamis dan diarahkan pada pertumbuhan, integritas, dan otonomi kepribadian, sikap yang sehat terhadap diri sendiri, orang lain, dan belajar. Kurikulum humanistik dipercayai sebagai fungsi kurikulum yang memberikan pengalaman kepada peserta didik untuk menunjang secara intrinsik tercapainya perkembangan dan kemerdekaan pribadi. Mereka memandang bahwa tujuan pendidikan sebagai proses perkembangan pribadi yang dinamis dan diarahkan kepada pertumbuhan, integrasi, otonomi kepribadian, sikap sehat kepada diri sendiri, orang lain, dan belajar.

\footnotetext{
${ }^{19}$ Ibid., h. 143.
} 
Konsep kurikulum humanistik memandang kurikulum sebagai alat untuk mengembangkan diri setiap individu peserta didik. Peserta didik diberi kesempatan untuk mewujudkan dirinya sesuai dengan potensi yang dimilikinya. Setiap individupun mempunyai kebutuhan yang harus dipenuhi mulai dari yang mendasar menuju yang lebih tinggi. Konsep ini melahirkan bentuk kurikulum yang berpusat pada anak didik atau child centered curriculum. Setiap peserta didik berkesempatan untuk belajar sesuai minat dan kebutuhannya masing-masing. Subtansinya berupa rencana belajar yang disusun bersama antara anak didik dan guru. Adapun tujuan kurikulum humanistik menekankan pada segi perkembangan pribadi, integrasi dan otonomi individu. Tujuan ini dipandang dapat menjadi sarana mewujudkan diri.

Kurikulum humanistik memiliki indikator menempatkan pembelajar sebagai subjek dalam pendidikan, dalam hal ini pendidikan yang bebas (liberating education) mendapatkan posisi yang sepantasnya. Esensi dari kurikulum ini adalah mempertemukan antara afektif domain (emotions, attitude, values) dengan kognitif domain (intelectual knowledge and abilities). Kedua aspek domain ini dapat ditemukan dalam karakter aktifitas pembelajaran. Sehingga dalam pendidikan humanistik meniscayakan akan terbangunnya suasana yang rileks, permissive, dan akrab, sehingga peserta didik dapat mengembangkan segala potensi yang ada dalam dirinya. ${ }^{20}$

Dengan demikian, memanusiakan manusia berarti: pertama, memberikan kesempatan kepada peserta didik untuk mengaktualisasikan dan menumbuhkembangkan alat-alat potensial dan potensi-potensi dasarnya atau disebut fitrah manusia. Kedua, Memenusiakan manusia berarti usaha memberikan kesempatan kepada peserta didik untuk mengembangkan alat-alat potensialnya seoptimal mungkin untuk dapat difungsikan sebagai sarana bagi pemecahan masalah-masalah hidup dan kehidupan, pengembangan ilmu pengetahuan dan teknologi serta budaya manusia, dan pengembangan sikap iman dan takwa kepada Allah SWT. ${ }^{21}$

Berdasarkan pengertian tersebut maka kurikulum pendidikan agama Islam dikembangkan bertolak pada kebutuhan dan minat peserta didik, yang mendorong mereka untuk dapat menumbuhkembangkan alat-alat potensial dan potensi-potensi dasar dan/atau fitrahnya, serta mendorongnya untuk mampu mengemban amanah baik sebagai 'abdullah maupun khalifahNya. Materi ajar dipilih sesuai dengan minat dan

\footnotetext{
${ }^{20} \mathrm{http} / / /$ deryjamaluddin.page.tl/Kurikulum-Humanistik.htm, diakses pada 22 Februari 2016.

${ }^{21}$ Muhaimin, Pengembangan Kurikulum..., h. 148.
} 
kebutuhannya. Peserta didik menjadi subyek pendidikan, dalam arti ia menduduki tempat utama dalam pendidikan. Guru/dosen berfungsi sebagai psikolog yang memahami segala kebutuhan dan masalah peserta didik, ia berperan sebagai bidan yang membantu peserta didik dalam melahirkan ide-idenya, dan sebagai pembimbing, pendorong, fasilitator dan pelayan bagi peserta didik.

Pengembangan kurikulum pendidikan agama Islam dilakukan oleh guru/dosen dengan melibatkan peserta didik, misalnya dalam penentuan tujuan dan pemilihan tematema pembelajaran pendidikan agama Islam. Tidak ada kurikulum standar, yang ada hanyalah kurikulum minimal yang dalam implementasinya dikembangkan bersama peserta didik. Isi dan proses pembelajarannya selalu berubah sesuai dengan minat dan kebutuhan peserta didik serta kontekstual. Karena itu, pendekatan humanitis dalam pengembangan kurikulum pendidikan agama Islam lebih cocok diterapkan dalam rangka pendalaman dan penghayatan serta pengalaman nilai-nilai akidah dan akhlak Islam untuk menyadari akan fungsi dan tujuan hidupnya sebagai khalifahNya di bumi. Nilai-nilai akidah dan akhlak Islam dikembangkan melalui proses keterpaduan antara pengetahuan, persaan atau penghayatan, dan tindakan, sehingga peserta didik memiliki karakter sebagai seorang muslim dan mukmin yang saleh. ${ }^{22}$

Di samping itu, pendekatan humanistik dapat dilakukan melalui pengembangan tema-tema pendidikan agama Islam yang berupa problem-problem yang aktual di masyarakat dan banyak menjadi perhatian para peserta didik. Melalui tema-tema tersebut, peserta didik dibimbing dan diarahkan untuk mampu memecahkan masalah tersebut dalam perspektif ajaran dan nilai-nilai Islam, atau ajaran dan nilai-nilai Islam itu dijadikan sebagai landasan moral dan etika dalam pengembangan ilmu pengetahuan, teknologi, budaya, dan aspek-aspek kehidupan lainnya. Bisa pula diterapkan dalam pembelajaran sejarah Islam yang dimaksudkan untuk menggali, mengembangkan 'ibrah (pelajaran) dari sejarah dan kebudayaan (peradaban) Islam, sehingga peserta didik mampu menginternalisasi dan tergerak untuk meneladani dan mewujudkan dalam amal perbuatan, serta dalam rangka membangun sikap terbuka dan toleran atau semangat ukhuwah Islamiyah dalam arti luas. ${ }^{23}$

\footnotetext{
${ }^{22}$ Ibid., h. 161.

${ }^{23}$ Ibid., h. 162.
} 


\section{Konsep Teori Belajar Humanisme}

Teori belajar humanistik pada dasarnya memiliki tujuan belajar untuk memanusiakan manusia. Oleh karena itu proses belajar dapat dianggap berhasil apabila si pembelajar telah memahami lingkungannya dan dirinya sendiri. Artinya peserta didik mengalami perubahan dan mampu memecahkan permasalahan hidup dan bisa menyesuaikan diri dengan lingkungannya.Dengan kata lain, si pembelajar dalam proses belajarnya harus berusaha agar lambat laun ia mampu mencapai aktualisasi diri dengan sebaik-baiknya. $^{24}$

Tujuan utama para pendidik adalah membantu siswa untuk mengembangkan dirinya, yaitu membantu masing-masing individu untuk mengenal diri mereka sendiri sebagai manusia yang unik dan membantu dalam mewujudkan potensi-potensi yang ada dalam diri mereka. ${ }^{25}$

Aplikasi teori humanistik dalam pembelajaran guru lebih mengarahkan siswa untuk berfikir induktif, mementingkan pengalaman, dan membutuhkan keterlibatan siswa secara aktif dalam proses belajar. Hal ini dapat diterapkan melalui kegiatan diskusi, membahas materi secara berkelompok sehingga siswa dapat mengemukakan pendapatnya masing-masing didepan kelas. Guru memberi kesempatan kepada siswa untuk bertanya apabila kurang mengerti terhadap materi yang diajarkan. Pembelajaran berdasarkan teori humanistik yang bersifat pembentukan kepribadian, hati nurani, perubahan sikap dan analisis terhadap fenomena sosial. Indikator dari keberhasilan aplikasi ini adalah siswa merasa senang bergairah, berinisiatif dalam belajar dan terjadi pola perubahan pola pikir, perilaku dan sikap atas kemauan sendiri. ${ }^{26}$

Konsep pendekatan humanistik dalam pendidikan menekankan pada perkembangan positif. Pendekatan yang berfokus pada potensi manusia untuk mencari dan menemukan kemampuan yang mereka punya dan mengembangkan kemampuan tersebut. Hal ini mencakup kemampuan interpersonal sosial dan metode untuk pengembangan diri yang ditujukan untuk memperkaya diri, menikmati keberadaan hidup dan juga masyarakat. Keterampilan atau kemampuan membangun diri secara

\footnotetext{
${ }^{24}$ Sukardjo dan Ukim Komarudin, Landasan Pendidikan, Konsep dan Aplikasinya, (Jakarta: PT. Raja Grafindo Persada, 2009), h. 56.

${ }^{25}$ M. Dalyono, Psikologi Pendidikan, (Jakarta: Rineka Cipta, 2012), h. 43.

${ }^{26}$ Herpratiwi, Teori Belajar dan Pembelajaran, (Bandar Lampung: Universitas Lampung, 2009), h. 39 .
} 
positif ini menjadi sangat penting dalam pendidikan karena keterkaitannya dengan keberhasilan akademik. ${ }^{27}$

Nilai-nilai penting yang ditumbuhkembangkan dalam pendidikan humanisme sebagai berikut:

a. Kejujuran (tidak menyontek, tidak merusak, dan bisa dipercaya)

b. Menghargai hak orang lain (menerima dan menghormati perbedaan individu yang ada, mau mendengarkan orang lain, menolong orang lain, dan bisa berempati terhadap problem orang lain)

c. Menjaga lingkungan

d. Perilaku (mau berbagi, menolong orang lain, ramah terhadap orang lain, dan berlaku pantas didepan publik)

e. Perkembangan pribadi (menjalankan tanggung jawab, menghargai kesehatan dan kebersihan fisik, mengembangkan bakat yang dimiliki secara optimal, mengembangkan rasa hormat dan rasa bangga terhadap diri sendiri, mengontrol perilaku, memiliki sikap berani, terhormat dan patriotik, serta menghargai keindahan). ${ }^{28}$

Kemampuan positif disini erat kaitannya dengan pengembangan emosi positif yang terdapat dalam dominan efektif, misalnya keterampilan membangun dan menjaga relasi yang hangat dengan orang lain, bagaimana mengajarkan kepercayaan, penerimaan, kesadaran, memahami perasaan orang lain, kejujuran interpersonal, dan pengetahuan interpersonal lainnya. Intinya adalah meningkatkan kualitas keterampilan interpersonal dalam kehidupan sehari-hari. Selain menitik beratkan pada hubungan interpersonal, para pendidiknya yang beraliran humanisme juga mencoba untuk membuat pembelajaran yang membantu anak didik untuk meningkatkan kemampuan dalam membuat, berimajinasi, mempunyai pengalaman, berintuisi, merasakan, dan berfantasi. Pendidik humanisme mencoba untuk melihat dalam spektrum yang lebih luas mengenai perilaku manusia. ${ }^{29}$

Melihat hal-hal yang diusahakan oleh para pendidik humanisme, tampak bahwa pendekatan ini mengedepankan pentingnya emosi dalam dunia pendidikan. Jadi bisa dikatakan bahwa emosi adalah karakteristik yang sangat kuat yang nampak dari para

\footnotetext{
${ }^{27}$ Sukardjo dan Ukim Komarudin, Landasan Pendidikan..., h. 57.

${ }^{28}$ Herpratiwi, Teori Belajar..., h. 41.

${ }^{29}$ Ibid., h. 42.
} 
pendidik beraliran humanisme. Karena berfikir dan merasakan saling beriringan, mengabaikan pendidikan emosi sama dengan mengabaikan salah satu potensi terbesar manusia. Kita dapat belajar menggunakan emosi kita dan mendapat keuntungan dari pendekatan humanisme ini sama seperti yang ingin kita dapatkan dari pendidikan yang menitikberatkan kognitif. ${ }^{30}$

\section{Prinsip-prinsip Kegiatan Pembelajaran dalam Pendekatan Humanistik}

Dalam buku Freedom to Learn, ia menunjukan sejumlah prinsip-prinsip dasar humanistik yang penting diantaranya sebagai berikut:

a. Manusia mempunyai kemampuan belajar secara alami

b. Belajar yang signifikan terjadi apabila materi pelajaran dirasakan murid mempunyai relevansi dengan maksud-maksudnya sendiri

c. Belajar yang menyangkut perubahan di dalam persepsi mengenai dirinya sendiri dianggap mengancam dan cenderung untuk ditolaknya

d. Tugas-tugas belajar yang mengancam diri lebih mudah dirasakan dan diasimilasikan apabila ancaman-ancaman dari luar itu semakin kecil

e. Apabila ancaman terhadap diri siswa rendah, pengalaman dapat diperoleh dengan berbagai cara yang berbeda-beda dan terjadilah proses belajar

f. Belajar yang bermakna diperoleh siswa dengan melakukannya

g. Belajar diperlancar bilamana siswa dilibatkan dalam proses belajar dan ikut bertanggung jawab terhadap proses belajar itu

h. Belajar atas inisiatif sendiri yang melibatkan pribadi siswa seutuhnya, baik perasaan maupun intelek, merupakan cara yang dapat memberikan hasil yang mendalam dan lestari

i. Kepercayaan terhadap diri sendiri, kemerdekaan, kreativitas lebih mudah dicapai terutama jika siswa dibiasakan untuk mawas diri dan mengkritik dirinya sendiri, penilaian dari orang lain merupakan cara kedua yang penting

j. Belajar yang paling berguna secara sosial di dalam dunia modern ini adalah belajar mengenai proses belajar, suatu keterbukaan yang terus-menerus terhadap pengalaman dan penyatuannya ke dalam diri sendiri mengenai proses perubahan itu. ${ }^{31}$

\footnotetext{
${ }^{30}$ Ibid., h. 43.

${ }^{31}$ Sukardjo dan Ukim Komarudin, Landasan Pendidikan..., h. 61-62.
} 
Siswa berperan sebagai pelaku utama (student center) yang memaknai proses pengalaman belajarnya sendiri. Diharapkan siswa memahami potensi diri, mengembangkan potensi dirinya secara positif dan meminimalkan potensi diri yang bersifat negatif. Tujuan pembelajaran lebih kepada proses belajarnya daripada hasil belajar.

Prinsip-prinsip kegiatan pembelajaran dalam pendekatan humanistic beberapa di antaranya yaitu:

a. Berpusat pada peserta didik

Pembelajaran berpusat pada peserta didik (student centred learning) merupakan pendekatan pembelajaran interaktif (interaktif gurupeserta didik-masyarakat-lingkungan alam, sumber/media lainnya). Pembelajaran centered learning ini sangat cocok digunakan pada pembelajaran pendidikan agama Islam, di mana peserta didik akan mampu menyerap pembelajaran dengan baik dan kemudian siswa dapat mempraktekkan langsung dalam lingkungan masyarakat.

b. Mengembangkan kreativitas peserta didik Peserta didik mampu mengembangkan kepekaan rasa karena peserta didik mendayagunakan kemampuan intelektual dan emosionalnya dalam memecahkan masalah-masalah yang dihadapi. Untuk itu, metode pembelajaran kelompok harus memberi peluang kepada peserta didik untuk berpikir secara konvergen dan divergen. Peserta didik mampu melatih keterampilannya untuk mengekspresikan perasaan estetiknya melalui media tertentu. Oleh karena itu, kegiatan pembelajaran pendidikan agama Islam yang bersifat rekreatif dan pelakonan perlu juga dilaksanakan. Artinya, peserta didik diberi kesempatan untuk mengekspresikan diri. Proses pendidikan dan pembelajaran secara yuridis formal dituntut harus diselenggarakan secara aktif, inovatif, kreatif, dialogis, demokratis dan dalam suasana yang mengesankan dan bermakna bagi peserta didik.

c. Menciptakan kondisi menyenangkan dan menantang Pembelajaran pendidikan agama Islam harus mampu dilaksanakan suasananya menyenangkan. Suasana yang menyenangkan adalah suasana belajar-mengajar memusatkan perhatiannya secara penuh pada belajar 
sehingga waktu curah perhatiannya tinggi. Menurut hasil penelitian, tingginya waktu perhatian terbukti meningkatkan hasil belajar. Keadaan aktif dan menyenangkan tidaklah cukup jika proses pembelajaran tidak efektif, yaitu tidak menghasilkan apa yang harus dikuasai siswa setelah proses pembelajaran berlangsung, sebab pembelajaran memiliki sejumlah tujuan pembelajaran yang harus dicapai. Jika pembelajaran hanya aktif dan menyenangkan tetapi tidak efektif, maka pembelajaran tersebut tak ubahnya seperti bermain biasa.

d. Mengembangkan beragam kemampuan yang bermuatan nilai Model pembelajaran dengan pendekatan lingkungan, bukan merupakan pendekatan pembelajaran yang baru, melainkan sudah dikenal, hanya saja sering terlupakan. Adapun yang dimaksud dengan pendekatan lingkungan adalah suatu strategi pembelajaran pendidikan agama Islam yang memanfaatkan lingkungan sebagai sasaran belajar, sumber belajar, dan sarana belajar. Hal tersebut dapat dimanfaatkan untuk memecahkan masalah lingkungan dan untuk menanamkan sikap cinta lingkungan. Konsep-konsep sains dan lingkungan sekitar siswa dapat dengan mudah dikuasai siswa melalui pengamatan pada situasi yang aktif. Dampak positif dari diterapkannya pendekatan lingkungan yaitu siswa dapat terpacu sikap rasa keingintahuannya tentang sesuatu yang ada di lingkungannya. Bekerja dan belajar yang berbasis lingkungan sekitar memberikan nilai lebih, baik bagi si pembelajar itu sendiri maupun bagi lingkungan sekitar.

e. Menyediakan pengalaman belajar yang beragam serta belajar melalui berbuat Menyediakan pengalaman belajar yang beragam, bekerja dan belajar yang berbasis lingkungan sekitar memberikan nilai lebih, baik bagi si pembelajar itu sendiri maupun bagi lingkungan sekitar. Katakanlah belajar pendidikan agama Islam maka lingkungan sekitar dapat menjadi contoh kehidupan alam semesta yang diciptakan oleh Allah SWT.

Prinsip-prinsip tersebut sebenarnya sejalan dengan Hadits Nabi SAW:

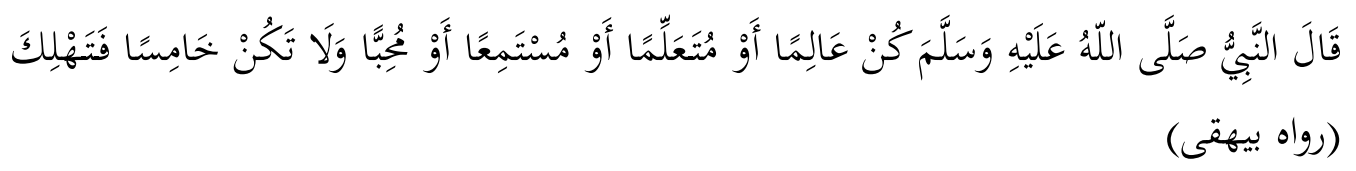


"Jadilah kamu orang yang alim, atau orang yang belajar, atau orang yang mendengar, atau orang yang cinta ilmu, janganlah kamu menjadi orang yang kelima (tidak alim, muta'allim, mustami'an dan muhibban), maka kamu akan hancur."

Dari Hadits tersebut dapat dipahami bahwa dalam kegiatan pembelajaran guru perlu memposisikan peserta didik sebagai orang yang berpengetahuan atau berpengalaman, sedangkan posisi guru sebagai fasilitator yang membimbing dan mengarahkan jalannya pembelajaran, atau memposisikan peserta didik sebagai orang yang sedang belajar, mangaktualisasikan dan mengembangkan potensi-potensinya. Adapun menjadikan peserta didik sebagai pendengar melalui metode ceramah dilakukan pada tahab berikutnya, yang berfungsi sebagai konfirmasi atau memperkuat apa yang dipelajari peserta didik, atau mediator bila terdapat pandangan-pandangan yang kontroversial, atau mungkin peserta didik sudah sangat memerlukan bantuan penjelasan guru, demikian seterusnya. ${ }^{32}$

Kurikulum ini berpusat pada siswa (student-centered) dan mengutamakan perkembangan afektif siswa sebagai prasyarat dan sebagai bagian integral dari proses belajar. Para pendidik humanistik yakin, bahwa kesejahteraan mental dan emosional siswa harus dipandang sentral dalam kurikulum agar belajar itu memberi hasil maksimal. Prioritasnya adalah pengalaman pelajar yang diarahkan pada tanggapan minat, kebutuhan, dan kemampuan anak. ${ }^{33}$

Dalam kaitannya dengan penentuan strategi pembelajaran PAI, maka pendekatan humanistik lebih menekankan kepada active learning (pembelajaran aktif), yang memiliki semboyan sebagai berikut:

a. What I hear, Iforget.

Yakni apa yang saya dengar mudah saya lupakan, karena guru berbicara 100200 kata per menit, sedangkan peserta didik mendengar 50-100 kata per menit, lama kelamaan semakin berkurang.

b. What I hear and see, I remember a little.

Yakni apa yang saya dengar dan saya lihat akan saya ingat sedikit atau sebentar, lama kelamaan lupa lagi.

\footnotetext{
${ }^{32}$ Muhaimin, Pengembangan Kurikulum..., h. 163.

${ }^{33}$ S. Nasution, Kurikulum dan Pengajaran, (Jakarta: PT Bumi Aksara, 1999), h. 45.
} 
c. What I hear, see, and ask question about or diccuss with someone else, I begin to understand.

Yakni apa yang saya dengar, lihat, dan tanyakan atau diskusikan dengan orang atau teman lain maka saya mulai mangerti.

d. What I hear, see, and discuss, and do, I acquirek nowledge and skill.

Yakni apa yang saya dengar, lihat, diskusikan dan laksanakan, maka saya memperoleh pengetahuan dan ketrampilan.

e. When I teac to another, I master.

Yakni ketika saya bisa mengajari orang atau teman lain, berarti saya menguasai.

Dengan demikian, pembelajaran aktif setidak-tidaknya sampai kepada tingkatan yang ketiga, dan diusahakan untuk sampai kepada tingkatan yang keempat dan kelima. Untuk mencapai tersebut, maka kegiatan pembelajaran harus dilandasi oleh prinsipprinsip. $^{34}$

Tugas guru adalah menciptakan situasi yang permitif dan mendorong siswa untuk mencari mengembangkan pemecahan sendiri. Pendidikan mereka lebih menekankan bagaimana mengajar siswa (mendorong siswa), dan bagaimana merasakan atau bersikap terhadap sesuatu. Tujuan pengajaran adalah memperluas kesadaran diri sendiri dan mengurangi kerenggangan dan keterasingan dari lingkungan. ${ }^{35}$

Pendekatan pengembangan kurikulum ini bertolak dari asumsi bahwa peserta didik adalah faktor yang pertama dan utama dalam pendidikan. Ia dapat menjadi subjek yang menjadikan pusat kegiatan pendidikan, dan mempunyai kemanpuan, potensi dan kekuatan untuk berkembang. Oleh karena itu, tugas pendidik hanya menciptakan situasi yang mendorong peserta didik untuk mencari dan mengembangkan pemecahan sendiri.

Pendekatan ini berkembang sebagai reaksi atas praktik pendidikan yang lebih menekankan segi intelektual saja, dengan peran utama dipegang oleh guru. Pendekatan ini memandang pendidikan merupakan upaya yang berusaha untuk menciptakan situasi yang baik, rileks dan akrab. Dengan situasi yang demikian kondusif, siswa dapat mengembangkan segala potensi dirinya. Pendidikan bertolak dari kebutuhan dan minat peserta didik. Peserta didik menjadi subyek pendidikan, dialah yang menduduki tempat

\footnotetext{
${ }^{34}$ Muhaimin, Pengembangan Kurikulum..., h. 162.

${ }^{35}$ Nana Syaodih Sukmadinata, Pengembangan Kurikulum, (Bandung: PT Remaja Rosdakarya, 2004), h. 87.
} 
utama dalam pendidikan. Pendidik menempati posisi kedua, bukan lagi sebagai penyampai informasi atau sebagai model dan ahli dalam disiplin ilmu. Pendidik lebih berfungsi sebagai psikolog yang mengerti segala kebutuhan dan masalah peserta didik.

Pendekatan humanis bersumber dari pendidikan progresif dan pendidikan romantik. Dalam pendidikan progresif, siswa merupakan satu kesatuan yang utuh, perkembangan emosi dan sosial sama romantik merupakan proses individual yang berisi rentetan pengembangan kemampuan-kemampuan anak, berkat interaksi dengan berbagai aspek dalam lingkungan maka terjadi rentetan pengembangan kemampuankemampuan anak. ${ }^{36}$

\section{Karakteristik Kurikulum Humanistik}

Tujuan utama dari humanisme adalah perkembangan dari aktualisasi diri manusia secara otonom dalam humanisme adalah sebagai orang fasilitator. Afeksi dan kebutuhan kognitif adalah kuncinya, sedangkan tujuannya adalah membangun manusia yang dapat mengaktualisasikan diri dalam lingkungan yang kooperatif dan suportif. Dijelaskan juga bahwa pada hakekatnya setiap manusia adalah unik, memiliki potensi individual dan dorongan internal untuk berkembang dan menentukan perilakunya. Karena itu, setiap diri manusia adalah bebas dan memiliki kecenderungan untuk tumbuh dan berkembang mencapai aktualisasi diri secara maksimal.

Kurikulum humanistik memiliki beberapa karakteristik yang tidak lepas dari karakteristik pendidikan humanis, diantaranya yaitu:

a. Adanya hubungan yang harmonis antara guru dan siswa. Untuk membangun suasana belajar yang baik, hubungan antara guru dan siswa harus pula dibangun seharmonis mungkin, sehingga guru tidak terkesan menakutkan, karena pengaruh psikis sangat mempengaruhi daya tangkap siswa dalam belajar, jika dilihat fenomena pembelajaran di sekolah, ada istilah guru killer ataupun dosen killer, ini merupakan bukti bahwa ternyata masih ada dalam proses pembelajaran yang mana guru atau dosen yang ditakuti oleh para siswa atau mahasiswa, dan berimplikasi terhadap daya tangkap siswa.

b. Adanya integritas yaitu dalam kurikulum humanistik menekankan kesatuanperilaku bukan saja yang bersifat intelektual (kognitif) tetapi juga

\footnotetext{
${ }^{36}$ Agus Zaenal Fitri, Manajemen Kurikulum..., h. 125.
} 
emosional dan tindakan, ini merupakan komitmen dari pendidikan humanis yang mana berupaya untuk mengembalikan pendidikan pada realitas sosial.

c. Adanya totalitas yaitu kurikulum humanistik harus mampu memberikan pengalaman yang menyeluruh (totalitas), bukan terpenggal-penggal (parsial).

d. Model evaluasi tidak ada kriteria pencapaian, seperti yang telah dijelaskan diatas bahwa kurikulum menekankan totalitas, oleh karena itu dalam model evaluasi yang dilakukan tidak ada kriteria pencapaian.

Dalam evaluasi, kurikulum humanistik berbeda dengan yang biasa. Model ini lebih mengutamakan proses dari pada hasil. Kalau kurikulum yang biasa terutama subjek akademis mempunyai kriteria pencapaian, maka dalam kurikulum humanistik tidak ada kriteria. Sasaran mereka adalah perkembangan anak supaya menjadi manusia yang terbuka, lebih berdiri sendiri. Kegiatan yang mereka lakukan hendak bermanfaat bagi siswa. Kegiatan belajar yang baik adalah yang memberikan pengalaman yang akan membantu para siswa memperluas kesadaran akan dirinya dan orang lain dan dapat mengambangkan potensi-potensi yang dimilikinya. Penilaiannya bersifat subjektif baik dari guru maupun para siswa. ${ }^{37}$

Evaluasi kurikulum humanistik berbeda dengan evaluasi kurikulum pada umumnya, bila evaluasi kurikulum konvensional ditentukan secara obyektif di mana ada kriteria untuk pencapaian, maka evaluasi kurikulum humanistik lebih memberi penekanan pada proses yang dilakukan. Maksudnya, kurikulum humanistik lebih tertarik dalam pertumbuhan tanpa memperhatikan tentang bagaimana pertumbuhan itu diukur atau ditentukan. Ahli humanis lebih mengutamakan proses daripada hasil sehingga kurikulum ini melihat kegiatan sebagai sebuah manfaat untuk peserta di masa depan. Mereka menghargai kelas yang memberikan pengalaman untuk membantu siswa menjadi lebih menyadari diri mereka sendiri dan orang lain dan mengembangkan potensi mereka sendiri secara unik. Guru humanistik merasa bangga tahu bagaimana siswa akan menanggapi kegiatan, baik dengan mengamati tindakan siswa atau dengan mencari umpan balik setelah latihan diberikan. ${ }^{38}$

\footnotetext{
${ }^{37}$ Sukmadinata, Nana Syaodih, Pengembangan Kurikulum..., h. 91.

${ }^{38} \mathrm{http}$ //nitanurrachmawatiatmasari.blogspot.co.id/2011/02/kurikulum-humanistik.html. diakses pada 02 Februari 2016.
} 


\section{F. Kesimpulan}

Pendekatan pengembangan kurikulum adalah cara kerja dengan menerapkan strategi dan metode yang tepat dengan mengikuti langkah-langkah pengembangan yang sistematis untuk menghasilkan kurikulum yang sistematis agar memperoleh kurikulum yang lebih baik. Penyusunan suatu komponen harus dinilai konsistensinya dan berkaitan dengan komponen-komponen lainnya sehingga kurikulum benar-benar terpadu (integratif) dan utuh.

Pengembangan kurikulum sesungguhnya adalah sebuah siklus, suatu proses berulang yang tidak pernah berakhir. Teori kurikulum setidak-tidaknya terdapat empat pendekatan yang dapat digunakan dalam pengembangan kurikulum, yaitu pendekatan subjek akademis, pendekatan humanistik, pendeketan teknologis, dan pendekatan rekonstruksi sosial.

Kurikulum humanistik dikembangkan oleh para ahli pendidikan humanistik. Kurikulum ini berdasarkan konsep aliran pendidikan pribadi (personalized education), yaitu John Dewey (progressive Education) dan J.J. Roasseau (Romantic Education). Aliran ini lebih memberikan tempat utama kepada siswa.

Prinsip-prinsip kegiatan pembelajaran dalam pendekatan humanistik yaitu: berpusat pada peserta didik, mengembangkan kreativitas peserta didik, menciptakan kondisi menyenangkan dan menantang, mengembangkan beragam kemampuan yang bermuatan nilai, menyediakan pengalaman belajar yang beragam serta belajar melalui berbuat.

\section{G. Daftar Pustaka}

Abdullah Idi, Pengembangan Kurikulum, Teori dan Praktik, Yogyakarta: Ar-Ruzz Media, 2010.

Agus Zaenal Fitri, Manajemen Kurikulum Pendidikan Islam, Bandung: Alfabeta, 2013.

Binti Maunah, PengembanganKurikulumBerbasisKompetens, Yogyakarta: Teras, 2009.

Departeman Agama RI, Pedoman Umun Pelajaran Umum Madrasah Aliyah, Jakarta: Rektorat Jenderal Kelembagaan Agama Depag RI, 2003.

Departemen Pendidikan Nasional, Undang-undang Nomor 20 Tahun 2003 tentang Sistem Pendidikan Nasional, Jakarta: 2004.

E. Mulyasa, Kurikulum Berbasis Kompetensi, Konsep, Karakteristik dan Implementasi, Bandung: PT Remaja Rosdakarya, 2004. 
Herpratiwi, Teori Belajar dan Pembelajaran, Bandar Lampung: Universitas Lampung, 2009.

http://deryjamaluddin.page.tl/Kurikulum-Humanistik.htm, diakses pada 22 Februari 2016.

http://nitanurrachmawatiatmasari.blogspot.co.id/2011/02/kurikulum-humanistik.html. diakses pada 02 Februari 2016.

Husni Rahim, Arab Baru Pendidikan Islam di Indonesia, Jakarta: Logos Wacana Ilmu, 2004.

M. Dalyono, Psikologi Pendidikan, Jakarta: Rineka Cipta, 2012.

Muhaimin, Pengembangan Kurikulum Pendidikan Agama Islam di Sekolah, Madrasah dan Perguruan Tinggi, Jakarta: PT Raja Grafindo Persada, 2007.

Nana Syaodih Sukmadinata, Pengembangan Kurikulum. Bandung: PT Remaja Rosdakarya, 2004.

Nik Haryati, Pengembangan Kurikulum Pendidikan Agama Islam, Bandung: Alfabeta, 2011.

Rahmat Raharjo, Pengembangan dan Inovasi Kurikulum Membangun Generasi Cerdas dan Berkarakter untuk Kemajuan Bangsa, Yogyakarta: Baituna Publishing, 2012.

S. Nasution, Kurikulum dan Pengajaran, Jakarta: PT Bumi Aksara, 1999.

Sukardjo dan Ukim Komarudin, Landasan Pendidikan, Konsep dan Aplikasinya, Jakarta: PT. Raja Grafindo Persada, 2009.

Wina Sanjaya, Kurikulum dan Pembelajaran: Teori dan Praktik Pengembangan Kurikulum Tingkat Satuan Pendidikan, Jakarta: Kencana, 2010.

Zainal Arifin, Pengembangan Manajemen Mutu Kurikulum Pendidikan Islam, Jogjakarta: Diva Press, 2006. 